\title{
Focusing on the Chinese health industry: an empirical enquiry on the TCM listed firms. Is large and private beautiful?
}

\section{Marco R. Di Tommaso* and Stefano Bonnini}

Department of Economics and Management, University of Ferrara,

Via Voltapaletto, 11, 44121 Ferrara, Italy

Email: dtmmrc@unife.it

Email: stefano.bonnini@unife.it

*Corresponding author

\section{Yue Qi}

School of Economics and Management,

South China Normal University,

55 Zhongshan W Ave,

Tianhe, Guangzhou,

Guangdong, China

Email: yueqi@m.scnu.edu.cn

\begin{abstract}
TCM is a key part of the Chinese healthcare system and TCM industries might play a growing role in the domestic and international markets. This work focuses on TCM listed companies in China. In particular, we study the effect of ownership and size on corporate performance. Multivariate permutation tests on the effects of ownership and size on corporate performance show that among the TCM listed companies, private companies perform better than state-owned ones, while big companies perform better than small ones. Moreover, the study shows that in TCM industry ownership has stronger effects than size on corporate performance.
\end{abstract}

Keywords: traditional Chinese medicine; TCM; health; industry; China; state owned enterprises; company ownership; company size; company performance.

Reference to this paper should be made as follows: Di Tommaso, M.R., Bonnini, S. and Qi, Y. (2017) 'Focusing on the Chinese health industry: an empirical enquiry on the TCM listed firms. Is large and private beautiful?', Int. J. Healthcare Technology and Management, Vol. 16, Nos. 1/2, pp.77-94.

\footnotetext{
Biographical notes: Marco R. Di Tommaso is a Full Professor of Applied Economic Studies. He currently teaches industrial economics and policy and development economics and policy at the Department of Economics and Management of the University of Ferrara (Italy). He studied in Italy and the UK. He has been a Visiting Professor in China and in the USA. He has actively participated in the debate within the scientific community by presenting his works at seminars, workshops and conferences both in Italy and abroad. His books and papers have been published and diffused at the national and international level. He has collaborated with Italian and foreign universities,
} 
specialised research centres, international institutions (UNIDO, CEPAL, UNDP, OECD) and national and local governments. His research focuses on the following topics: industrial sectors; industrial policy; local development, SMEs and clusters; international industry; Chinese economy and industry; health industry.

Stefano Bonnini is an Associate Professor of Statistics in the Department of Economics and Management at University of Ferrara (Italy). He authored papers which are published in international journals and books published by publishers of recognised worldwide importance. His main research interests concern nonparametric statistical methods and statistics applied to economics and social sciences, health sciences and engineering.

Yue Qi is an Associate Professor at the School of Economics and Management of South China Normal University in China. He received his $\mathrm{PhD}$ in Management at South China University of Technology in 2010. His current research interests are corporate acquisitions and mergers and strategic alliances in China.

\section{Introduction ${ }^{1}$}

The ageing population, decades of the one-child policy and, in general, the increase in income associated to economic growth have been producing a continuous rise (and change) in Chinese people's demand for health.

Chinese Government authorities recognise the centrality of the health issue. According to the Twelfth Five-Year Plan for Health Sector Development: "The new stage of socioeconomic development brings about multiple health challenges, and the task of the health sector becomes more formidable. China, at a time of rapid industrialization and urbanization as well as accelerated aging, faces more complicated health issues. On the one hand, we face the ever-present severe communicable diseases, a growing threat from non-communicable diseases and mental illnesses, and the potential threat from emerging diseases and traditional deadly infectious diseases. On the other hand, changes in ecological environment and lifestyle, and issues such as food and drug safety, occupational health, drinking water safety, as well as environmental issues pose more threats to the health of people. The recurring natural disasters, accidents and social security incidents increased the demand for health assurance. The contradiction between supply and demand of medical and health services becomes more intense, and the ideology and model of service must be adjusted accordingly in a timely manner ${ }^{2}$."

International institutional observers share similar views. According to the World Bank: "The population is aging and there is a surge in non-communicable diseases such as cancer, diabetes and heart disease. The number of people over 65 years old in China is now at 140 million and is expected to increase to 230 million by 2030 . Infectious diseases have been replaced by non-communicable diseases as the greatest health threat to Chinese people, accounting for more than 80 percent of the 10.3 million deaths every year. Those diseases are exacerbated by high-risk behaviors such as smoking, sedentary lifestyles and alcohol consumption, as well as environmental factors such as air pollution. At the same time, with higher economic growth and personal incomes, people are demanding more and better health care" (World Bank, 2016). 
No one doubts that the capacity of answering the growing expectations in healthcare is one of the biggest challenges for China and it is a central issue for the sustainability of the whole process of economic and social change (World Bank 2016; Huang, 2013; Daemmrich, 2013; Di Tommaso et al., 2013). In the same perspective, the capacity of growth of the national health industry should be considered a priority for China ${ }^{3}$.

In this framework, the traditional chinese medicine (TCM) industry in China has to be regarded as a strategic sector (Di Tommaso and Huang, 2010). Its development and its capacity of answering to the variety of needs of the contemporary Chinese population have to be considered a priority. It is important to understand and to study the strengths and weaknesses of this industry, given that it is still playing a central role in responding to the Chinese people's demand for health. Chinese Government authorities recognise the importance of TCM, as the Twelfth Five-Year Plan for Health Sector Development clearly argues: we will further improve the TCM service system and strengthen the development of county level TCM hospitals. We will push forward practice and research for preventing major diseases with TCM. We will actively develop TCM treatment and preventive care, and recognise a central role to the advantages and functioning of TCM in basic public health services. We will improve the TCM service capacity at primary health facilities and promote appropriate TCM technology, encourage retail pharmacies to provide TCM diagnosis services. We will improve the protection, research, development and rational use of TCM resources, and accelerate the development of the TCM industry. We will train a team of high-quality TCM doctors and foster a team of TCM masters. We will primarily establish a TCM inheritance and innovation system by strengthening our work in this area. We will reinforce the inheritance and development of national medicines and promote integration between western medicine and TCM. We will actively push forward the development of TCM related legislation, information and standards. We will actively develop TCM culture and encourage TCM to go global. We will study and generate health insurance plans and essential medicine policies that encourage TCM services, and improve the mechanism that assures the development of TCM" (The Twelfth Five-Year Plan for National Economic and Social Development of the People's Republic of China).

The most important market for the TCM industries is, of course, China. In mainland China the diffusion of TCM is evident and it has not lost its traditional central position in healthcare practices. According to World Health Organization $(2013)^{4}$, in China there are 440,700 health-care institutions providing TCM services. They have 520,600 patient beds, including all levels of TCM hospitals and general hospitals, clinics and health ambulatories in urban and rural areas. The great majority of general hospitals $(90 \%)$ include at least one TCM department and they provide TCM health services for both outpatients and inpatients. In China, government and private insurances fully cover TM therapies and services: doctors and patients are free to follow TCM or western medicine for health-care services. Looking at the domestic market for drugs, in 2012 the sales revenue of China's pharmaceutical industry amounted to 1,515.61 billion yuan ${ }^{5}$, among which the sales revenue of TCM was 506.71 billion yuan.

In this scenario, it is also true that the Chinese TCM industry seems to have important opportunities to grow also abroad, given that the use of T\&CM (Traditional and Complementary Medicine ${ }^{6}$ ) is experiencing a clear boom also outside China. Not only large Chinese communities of expatriates and immigrants living abroad (in particular in the US, Europe and Australia) demand for TCM but also foreign patients and doctors 
have been showing a growing interest in the so-called alternative healthcare practices. According to WHO: “...over 100 million Europeans are currently T\&CM users, with one fifth regularly using T\&CM and the same number preferring health care which includes T\&CM. There are many more T\&CM users in Africa, Asia, Australia and North America" (WHO, 2013).

In this framework, it is important to study the status of the TCM Chinese industry that has been definitively under-explored in the existing economic literature. How this industry is today organised is a relevant field for economic analysis. In China there are nowadays 48 main large-size companies specialised in TCM. They are the listed companies operating in the TCM sector, 13 of them are state owned enterprises (SOEs) while the rest have private ownership and management. Furthermore, official statistical sources records a community of 2.252 enterprises involved in the manufacturing of a variety of TCM products: they are all not-listed companies and the majority of them can be classified as SMEs ${ }^{7}$.

This paper focuses on the listed TCM companies and, in particular, we study how ownership (state-owned vs. private) and size (large vs. small) might affect TCM company performances. It is well known: economics, management and business theories have very often emphasised how large companies are supposed to perform better than small-size firms. Analogously, a large literature has traditionally highlighted the inefficiencies of state-owned enterprises suggesting that, by definition, private property would guarantee better performances to companies. However, it also clear that these general statements need further specifications and empirical confirmations based on specific industry, territorial and institutional contexts. It has been showed that in some circumstances small and medium size companies might perform better than large enterprises. Similarly, it has also been demonstrated that company performances are not associated to ownership (private vs. public) but to the degree of competition characterising one specific industry.

In this scenario we decided to investigate the specific case of the Chinese TCM industry. We discuss if, in this specific case, ownership and firm size have a significant effect on the performance of enterprises. And, if this will be proved to be the case, we will try to measure which of the two effects is greater. Section 2 provides some statistical data on TCM industry and describes the research goals in details. Section 3 reviews the relevant theory and proposes our hypotheses. Section 4 introduces the methodology used in this research and Section 5 shows the results of the analysis to testify the hypotheses. Section 6 presents the final remarks.

\section{Research objectives}

TCM refers to the drugs applied for preventing, diagnosing or treating disease, or adjusting physical functions under the guidance of TCM theory, and it is mainly represented by botanical drugs, as well as by some animal and mineral medicines (Zhao, 2015).

TCM industry refers to the production, processing, services, research and other economic activities related to TCM principles (Feng and Chang, 2010). According to different manufacturing techniques, TCM products mainly include TCM raw materials, prescription TCM products, Chinese herbal pieces, etc. Based on the industrial classification of China's national economy, it is possible to divide the TCM industry into 
three categories: TCM agriculture, TCM manufacturing industry and TCM commerce (Figure 1):

1 TCM agriculture mainly refers to the collection, cultivation, hunting of traditional Chinese medicinal materials.

2 TCM manufacturing industry includes the processing of Chinese herbal pieces (Yinpian), the production of TCM prescription medicines and the production of TCM healthcare products. It also includes related industries, such as pharmaceutical machineries, auxiliary materials, packaging materials, vegetable drug processing, etc.

3 TCM commerce refers to the storage, transportation, sale and other services closely related to the TVM industry, including exports of TCM (Feng, 2009).

Figure 1 A taxonomy of TCM industry activities

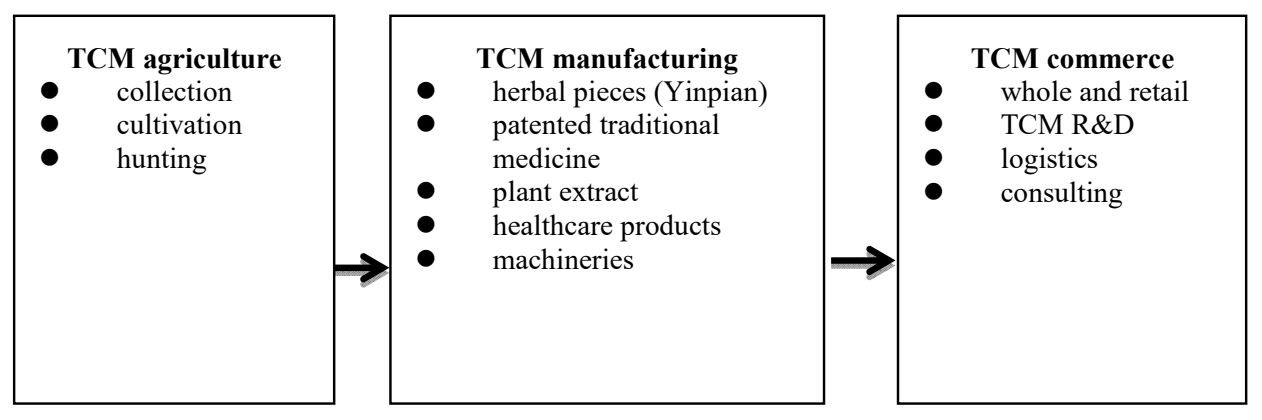

Source: Elaboration of the authors

Table 1 Sales of TCM and WM products from 2003 to 2012 (billion yuan)

\begin{tabular}{ccccccc}
\hline Year & $\begin{array}{c}\text { WM } \\
\text { sales }\end{array}$ & $\begin{array}{c}\text { Yearly } \\
\text { growth (\%) }\end{array}$ & $\begin{array}{c}\text { TCM } \\
\text { sales }\end{array}$ & $\begin{array}{c}\text { Yearly } \\
\text { growth (\%) }\end{array}$ & $\begin{array}{c}\text { Total } \\
\text { sales }\end{array}$ & $\begin{array}{c}\text { Yearly } \\
\text { growth (\%) }\end{array}$ \\
\hline 2003 & 179.73 & & 77.37 & & 257.1 & \\
2004 & 206.94 & 15.14 & 89.12 & 15.18 & 296.06 & 15.15 \\
2005 & 262.55 & 26.87 & 110.34 & 23.81 & 372.89 & 25.95 \\
2006 & 289.39 & 10.22 & 135.51 & 22.81 & 424.9 & 13.95 \\
2007 & 365.92 & 26.45 & 162.38 & 19.83 & 528.3 & 24.34 \\
2008 & 479.03 & 30.91 & 198.85 & 22.46 & 677.88 & 28.31 \\
2009 & 566.25 & 18.21 & 239.87 & 20.63 & 806.12 & 18.92 \\
2010 & 688.41 & 21.57 & 310.81 & 29.58 & 999.22 & 23.95 \\
2011 & 855.87 & 24.33 & 408.93 & 31.57 & $1,264.8$ & 26.58 \\
2012 & $1,008.90$ & 17.88 & 506.71 & 23.91 & $1,515.61$ & 19.83 \\
\hline
\end{tabular}

Source: Chinese Pharmaceutical Yearbook, various years.

In 2012, the cultivation of TCM raw materials across the country covered an area of 1.552 million hectares, accounting for $1 \%$ of the total crop planting area. There were 17 professional markets of traditional Chinese medicinal materials, covering 1.436 million $\mathrm{m}^{2}$, and sales amounted to 79.79 billion yuan (NBS, 2014). In 2012, the total sale revenue of TCM products was 506.71 billion Yuan, accounting for $1 / 3$ of the sales 
revenue of medicine products throughout the country. In recent years, the yearly growth rate of TCM sales has always been higher than western medicine and almost above $20 \%$ (Table 1).

The export of TCM products in 2012 reached about 2.5 billion USD, mainly plant extract and traditional Chinese medicinal materials. The export of Chinese patented medicine and TCM for health care was instead relatively low, with decreasing growth rates in the last few years (Table 2).

Table 2 Export of TCM products (100 million dollars)

\begin{tabular}{cccccc}
\hline Year & Total & Health products & Plant extract & Prescription TCM & $\begin{array}{c}\text { TCM Yinpian and } \\
\text { raw materials }\end{array}$ \\
\hline 2006 & 10.91 & 0.69 & 4.77 & 1.35 & 4.10 \\
2007 & 11.80 & 0.70 & 4.80 & 1.50 & 4.80 \\
2008 & 13.09 & 0.87 & 5.30 & 1.71 & 5.21 \\
2009 & 14.62 & 0.89 & 6.55 & 1.63 & 5.54 \\
2010 & 19.44 & 1.61 & 8.15 & 1.93 & 7.76 \\
2011 & 23.32 & 2.06 & 11.29 & 2.30 & 7.67 \\
2012 & 24.99 & 2.13 & 11.64 & 2.65 & 8.58 \\
\hline
\end{tabular}

Source: Chinese Pharmaceutical Yearbook, various years.

In 2008 there were more than 2,000 enterprises engaged in the TCM industry, with 422 of them (more than 20\%) registering a loss. This has been partly due to the impact of the financial crisis on the pharmaceutical industry and partly to the new GMP certification, which sets higher requirements on enterprises, forcing some of them to exit the market (Table 3). However, the number and percentage of unprofitable enterprises gradually declined in recent years (Table 3 ).

Table 3 Number of TCM firms from 2007 to 2012

\begin{tabular}{lccc}
\hline Year & Total $n$. of companies & Number of losing companies & $\%$ \\
\hline 2008 & 2,150 & 422 & 19.63 \\
2009 & 2,256 & 373 & 16.53 \\
2010 & 2,369 & 319 & 13.47 \\
2011 & 2034 & 165 & 8.11 \\
2012 & 2238 & 178 & 7.95 \\
\hline
\end{tabular}

Source: Chinese Pharmaceutical Yearbook, various years.

The analysis presented in the subsequent part of the article concentrates on the impact of ownership and scale of listed TCM companies on the corporate performance.

The first aim of the study is to understand what kind of ownership (private or public) and what scale (small or large) have an impact on corporate performance. Secondly, we want to understand which of the two has the stronger effect.

The significance of our exercise is twofold:

a For firms, it aims to help them in their strategic choice of the internal governance structure and in their decision to expand or to reduce their scale. The nature of ownership right directly determines if the enterprise can construct a proper governance structure. 
b For the government, it is necessary to know what type of enterprise would be more effective to promote while shaping the policy aims and tools. Consequently, to clarify the impact of ownership and scale on corporate performance is crucial for both business strategy and government decisions.

\section{Theory and hypothesis}

\subsection{Ownership and enterprise performances}

There is a wide and established international literature on which kind of ownership allows for the best company performances, if state-owned or private enterprises (Millward, 1982; Boardman and Vining, 1989; Vining and Boardman, 1992; Anderson et al., 1997; Wolf, 2009; Cornett et al., 2010; Bogart and Chaudhary, 2015; Färe et al., 1985). In Western countries academic and policy maker circuits, with few exceptions, the general statement is that private ownership has to be recommended because of its superior performances. This argument has been quite powerful and in the last decades it has inspired privatisation programs and reforms in Europe, North America and in many other emerging and developing countries (World Bank, 1990, 1996; Parker and Kirkpatrick, 2005; Roland, 2008).

In this context of international consensus, what is interesting here to note is that also China has gradually accepted this perspective. Many empirical analyses carried out by Chinese scholars have intended to prove that private enterprises are more efficient than state-owned enterprises (SOEs). For instance, Yao (1988) and Liu (2004) compared the technical efficiency of various types of enterprises and found out that the technical efficiency of private enterprises was the highest, followed by foreign-funded enterprises and collective enterprises, with SOEs being the less efficient. Song and Chang (2009) used data on different industries in 2006 and 2007, including state-owned firms, state-owned holding industrial enterprises and private industrial enterprises, and found out that the efficiency of private enterprises was the highest with DEA method analysis. Liu and Shi (2010) used provincial panel data of 29 regions from 1985 to 2004 and discovered that SOEs suffered from efficiency losses and soft budget constraints, which instead boosted the development of private enterprises, and prevented the entire economy from growing. Interesting in this area of study are the results of Li and Hazel (2010): they used a difference-in-difference model to analyse data from 1996 to 2006, discovering that before 2003, the performance of state-owned enterprises was much lower than other enterprises, but there were no evident distinctions in performance after 2003.

In this general scenario it is also true that sector-based studies might arrive to different results and that, with few exceptions (Hao, 2011; Jing 2011), there is a lack of studies on the specific case of the Chinese TCM industry. In the light of these considerations we suggest our first hypothesis:

H1 Private TCM companies have better performance than state-owned TCM companies.

\subsection{Company size and performance}

Also in the case of the relationship between company size and performance, the international literature has produced a huge number of works. Even if some authors have 
suggested that in some circumstances small can also be beautiful, large size has always been recommended for companies wishing to promote their efficiency, competiveness and innovation capacity (Viner 1932; Stigler, 1946; Bain, 1956; Hanoch, 1975; Panzar and Willing, 1977; Silvestre, 1987).

In the last decades the debate in China has confirmed this perspective focusing on the Chinese contemporary economic reality. The Chinese government in its catching-up policies has always promoted large size enterprises to achieve efficiency and technological upgrading (Di Tommaso et.al, 2013; Rubini and Barbieri, 2013). The Chinese academic literature too has worked on this topic and, in general, results confirm what the international literature developed while studying the experience of western economies. Several empirical studies on China's industry (Zhang and Sun, 2010; Wang and Chen, 2013) show how enterprise scale has a positive effect on productivity. Besides lower costs, stronger profitability and higher market competitiveness, large-scale enterprises can accumulate more capital for production, technology innovation and staff training, all impacting on productivity (Zhang and Sun, 2010; Wang and Chen, 2013).

However, very few scholars have analysed the scale-versus-performance issue in the Chinese TCM industry. Despite this lack of literature, it seems reasonable to expect that company scale has an impact on profitability also in the case of contemporary Chinese TCM industry. Generally speaking, larger enterprises are expected to better exploit scale economies, and enjoy higher advantages in resource acquisition, market power and channel expansion, etc. These considerations lead to our second hypothesis.

H2 Large TCM companies have better performances than small TCM companies.

\subsection{Comparison between the role of ownership and scale on performance}

Given the two dimensions we discussed so far (size and ownership), it is also interesting to study if - in the specific case of the Chinese TCM industry - company ownership has a higher (or lower) influence on performance than company size. As we noted above, the specialised international and Chinese economic literature is not particularly rich in this field. Nevertheless, it is reasonable to argue that the existing literature shows a greater emphasis on the market-oriented reform and the positive effect that private ownership might play in improving TCM company performances (WHO, 2013; NBS, 2014; Hao, 2011; Jing, 2011). For this reason we believe that it would be relevant to test also the following hypothesis:

H3 Corporate ownership has a higher influence on performance than corporate size.

\section{Methodology}

This study focuses on all the 48 listed TCM companies in China in 2014. All data have been extracted from the 2014 annual reports of these companies. The appendix presents the basic information of these companies.

As mentioned above, the goal of the empirical study presented in this research consists of testing some hypotheses concerning the effect of ownership and size on the economic performance of TCM listed companies. Ownership and size are dichotomous variables that classify TCM companies as private-owned vs. state-owned and big vs. small. Studying the effect of one variable, we compare groups of companies, 
defined according to a given dichotomous variable (factor), net of the confounding effect of another dichotomous variable (covariate) (VanderWeele and Shpitser, 2013), to test whether the factor has a significant effect on performance. In order to test the ownership effect, ownership takes the role of factor and size takes the role of confounder. For testing the size effect, the opposite classification holds. Instead, the test on the joint effect of both mentioned variables assumes that the two variables jointly contribute to the definition of one factor, by identifying four groups of companies:

1 private-owned and big

2 private-owned and small

3 state-owned and big

4 state-owned and small.

It is worth noting that, since the hypotheses under test are directional, we are not only investigating the significance of the effects. In other words, we look for empirical evidence in favour of the hypothesis that the performance of private-owned companies is greater than the performance of state-owned companies, and in favour of the hypothesis that big companies present a better performance than small ones. Furthermore, we test a specific order of the four groups of companies defined above, according to the economic performance.

An element of complexity of the problem is given by the multivariate nature of the variable that represents the economic performance (PERF). As a matter of fact, we take into account two different variables of economic performance:

- $\quad$ ROE: return on equity

- $\quad$ EPS: earning per share.

Hence, since each of the two variables represents a partial aspect of the performance, every mentioned testing problem can be broken down into three sub-problems corresponding to the partial aspects under investigation. For example, in the problem regarding the effect of ownership, under the null hypothesis of equal performance of private-owned (PO) and state-owned (SO) companies, the null hypothesis $H_{0}$ states the joint equality of ROS, EPS and ROE between the two groups. In other words, the null hypothesis is true when the equality of the performance of private-owned and state-owned companies is jointly true for ROS, EPS and ROE. Formally:

$$
H_{0}:\left[P E R F_{P O}=P E R F_{S O}\right] \equiv\left[\left(E P S_{P O}=E P S_{S O}\right) \text { and }\left(R O E_{P O}=R O E_{S O}\right)\right] \text {. }
$$

Under the alternative hypothesis, the equality is not true for at least one of the two variables of performance, that is at least one of the three variables of performance takes greater values in the group of private-owned companies. Formally:

$$
H_{1}:\left[P E R F_{P O}>P E R F_{S O}\right] \equiv\left[\left(\operatorname{EPS}_{P O}>E P S_{S O}\right) \operatorname{or}\left(R O E_{P O}>R O E_{S O}\right)\right] .
$$

When investigating the effect of size, similar hypotheses can be defined, that is:

$$
\begin{aligned}
& H_{0}:\left[P E R F_{B I G}=P E R F_{S M A L L}\right] \\
& \quad \equiv\left[\left(E_{B P S_{B I G}}=E P S_{S M A L L}\right) \text { and }\left(R O E_{B I G}=R O E_{S M A L L}\right)\right]
\end{aligned}
$$


and

$$
\begin{aligned}
& H_{1}:\left[\operatorname{PERF}_{B I G}>P E R F_{S M A L L}\right] \\
& \quad \equiv\left[\left(E S_{B I G}>E P S_{S M A L L}\right) \operatorname{or}\left(\operatorname{ROE}_{B I G}>\operatorname{ROE}_{\text {SMALL }}\right)\right]
\end{aligned}
$$

To take into account the confounding effect of one factor, when testing the positive effect of the other one, stratification can be applied (Arboretti and Bonnini, 2009). Hence, companies are classified into two groups (strata), according to the confounding variable, the testing problem is performed within each stratum and a suitable combination of the within-stratum tests is applied. This implies that the overall testing problem is broken down into four partial tests: two response variable times two strata (Figure 2).

Such a complex problem can be solved by means of a nonparametric methodology. Specifically, we can apply a combined permutation test that consists in a multiple permutation test with combination of the partial p-values through a suitable combining function (Bonnini et al., 2014). The application of one-sided two-sample permutation (partial) tests on means implies that neither normality nor other distributional assumptions, with the only exception of exchangeability under $H_{0}$, are required. The application of a suitable combining function allows to transform the multivariate test statistic into a univariate test statistic. We used the Fisher combining function because there is no expectation about the possible number of true alternative hypotheses. The null distribution of this statistic implicitly takes into account the dependence structure of the partial statistics (through a suitable permutation strategy). Thus, there is no need of assuming a specific multivariate distribution function (like in the likelihood ratio test) for computing the overall $\mathrm{p}$-value. This distribution-free testing procedure is very flexible, robust, powerful and can be applied in wide range of different situations.

Figure 2 Breakdown of the multivariate multistrata test on performance for the comparison of two groups of companies (see online version for colours)

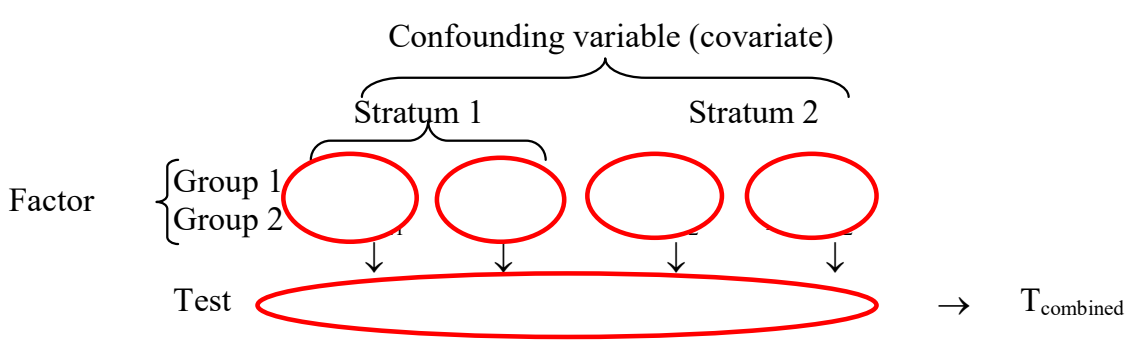

Source: Elaboration of the authors.

For the test on the ordering of the four groups, by denoting with 1, 2, 3 and 4 the compared groups of companies we have:

$$
H_{0}:\left[\left(E P S_{1}=E P S_{2}=E P S_{3}=E P S_{4}\right) \text { and }\left(R O E_{1}=R O E_{2}=R O E_{3}=R O E_{4}\right)\right]
$$

and

$$
H_{1}:\left[\left(E P S_{1} \geq E P S_{2} \geq E P S_{3} \geq E P S_{4}\right) \text { and }\left(R O E_{1} \geq R O E_{2} \geq R O E_{3} \geq R O E_{4}\right)\right]
$$


with the strict inequality $(>)$ true under the alternative hypothesis in at least one case (one pair of groups and one variable).

Even for this problem we can find a methodological solution within the family of combined permutation tests, by considering the trivariate permutation test on stochastic ordering, with method and properties similar to those of the two-sample test described above.

\section{Results}

In Table 4 some basic statistics are shown. We note that the sample sizes of the four groups of TCM companies, defined by jointly considering ownership and size, are very small: from a minimum of six to a maximum of 24 . This is one reason more for choosing nonparametric methods for our testing problems. With such small sample sizes, the real underlying distribution of data cannot be tested with reliable procedures and asymptotic distributional properties, such as those related to the central limit theorem, do not hold.

Table 4 Means of the performance indicators in different types of the listed TCM companies

\begin{tabular}{lccc}
\hline & Number & EPS & ROE \\
\hline State-owned & 13 & 0.758 & 6.13 \\
Private-owned & 35 & 0.706 & 15.67 \\
& & & \\
Small & 31 & 0.596 & 11.73 \\
Big & 17 & 0.947 & 15.56 \\
& & & \\
Private_big & 11 & 0.8427 & 16.10 \\
Private_small & 24 & 0.6433 & 15.48 \\
State_big & 6 & 0.9717 & 10.75 \\
State_small & 7 & 0.5743 & 2.171 \\
\hline
\end{tabular}

Source: Elaboration of the authors.

The result of the test on the effect of ownership on performance is reported in Table 5. For estimating the multivariate permutation p-values of the test, 1,000 conditional Monte Carlo iterations were considered (Bonnini et al., 2014). According to the significance level $\alpha=0.10$ and the overall p-value, $0.092<\alpha$, we have a significant positive effect of private ownership respect to public ownership. To attribute the overall significance of the test to one or more partial tests, a closed testing method was applied for controlling the multiplicity and adjusting the partial p-values, thus avoiding an increase of the type first error probability (Arboretti et al., 2012). According to the adjusted p-values (compared with $\alpha$ ), we have significance only in the case of the partial test $T_{4}$, that is private-owned TCM listed companies present a greater performance than state-owned TCM listed companies but this is true only in the case of small companies and if we consider ROE as performance variable. We have no empirical evidence of better performance in terms of EPS and for big companies. 
Table 5 Test on the effect of ownership on performance of listed TCM companies

\begin{tabular}{lcccc}
\hline \multicolumn{5}{c}{ Size (covariate) } \\
\hline Big & \multicolumn{5}{c}{ Small } \\
\hline $\mathrm{T}_{1}$ & $\mathrm{~T}_{2}$ & $\mathrm{~T}_{3}$ & $\mathrm{~T}_{4}$ & $\mathrm{~T}_{\text {combined }}$ \\
EPS & ROE & EPS & ROE & \\
& & & & Overall p-value \\
0.572 & 0.335 & 0.572 & 0.092 & 0.092 \\
\hline
\end{tabular}

Source: Elaboration of the authors.

Note: $H_{1}:\left[P E R F_{P O}>P E R F_{S O}\right], \alpha=0.10$.

The result of the test on the effect of size to performance is reported in Table 6. Again we considered 1,000 conditional Monte Carlo iterations and $\alpha=0.10$. The combined $\mathrm{p}$-value of $0.058<\alpha$ implies that there is a significant positive effect of size on performance. Even in this analysis, to attribute the overall significance to one or more partial tests, a closed testing method was applied. According to the adjusted p-values, we have significance only in the case of the partial test $T_{1}$, that is big TCM listed companies present a greater performance than state-owned TCM listed companies but this is true only in the case of private companies and if we consider EPS as performance variable. We have not empirical evidence of better performance in terms of ROE and for state-owned companies.

Table 6 Test on the effect of size on performance of listed TCM companies

\begin{tabular}{|c|c|c|c|c|}
\hline \multicolumn{4}{|c|}{ Ownership (covariate) } & \multirow[b]{3}{*}{$\mathrm{T}_{\text {combined }}$} \\
\hline \multicolumn{2}{|r|}{ Private-owned } & \multicolumn{2}{|c|}{ State-owned } & \\
\hline $\mathrm{T}_{1}$ & $\mathrm{~T}_{2}$ & $\mathrm{~T}_{3}$ & $\mathrm{~T}_{4}$ & \\
\hline \multirow[t]{2}{*}{ EPS } & ROE & EPS & ROE & \\
\hline & & & & Overall p-value \\
\hline 0.085 & 0.133 & 0.341 & 0.258 & 0.058 \\
\hline
\end{tabular}

Source: Elaboration of the authors.

Note: $H_{1}:\left[P E R F_{B I G}>P E R F_{S M A L L}\right], \alpha=0.10$.

Table 7 Stochastic ordering test result

\begin{tabular}{lcc}
\hline \multicolumn{3}{c}{$P / B>P / S>S / B>S / S$} \\
\hline$T_{1}$ & $T_{2}$ & $T_{\text {combined }}$ \\
\hline EPS & ROE & overall p-value \\
0.380 & 0.058 & 0.058 \\
\hline
\end{tabular}

Source: Elaboration of the authors.

Note: $H_{1}:\left[P E R F_{P / B}>P E R F_{P / S}>P E R F_{S / B}>P E R F_{S / S}\right], \alpha=0.10$.

The result of the stochastic ordering test on the comparison of the effect of size and ownership is reported in Table 7. Again we considered 1,000 conditional Monte Carlo iterations and $\alpha=0.10$. The combined p-value of $0.058<\alpha$ implies that there is a significant order that performance of the four groups is the same as we proposed. In this analysis, to attribute the overall significance to one or more partial tests, a closed testing 
method was applied. According to the adjusted p-values, we have significance only in the case of the partial test $T_{2}$, which means this is true only if we consider ROE as performance variable. We have no empirical evidence of this order in terms of EPS.

\section{Discussion of the results and final remarks}

Based on all 48 TCM listed companies in China, we have studied the effect of ownership and size on corporate performance. First, we used a NPC software to test the effect of ownership and size on corporate performance. Then, we checked if ownership or size has bigger influence on performance in TCM industry. The results are discussed in the following sentences:

1 Private TCM companies show better performance than state-owned TCM companies. It might be argued that corporate governance mechanisms in private TCM listed company make the difference. In private companies, shareholders and managers are both guided by profit-seeking attitudes and their actions are able to encourage efficiency and innovation. On the contrary, in state owned enterprises managers might also be influenced by other goals defined in accordance with (local and national) policy makers in the framework of broader political scenarios. Moreover, this special relationship between managers and government officials might encourage rent-seeking and clientelism causing negative effects on company performance.

2 Big TCM companies show better performances than small TCM companies. It might be asserted that economies of scale are important in the contemporary Chinese TCM industry. TCM large enterprises have economic advantages that can be reasonably explained according to many reasons: access to inputs, human resources management and recruiting, production and processing, R\&D, learning by doing and knowledge management, sale channels and distribution, reputation and relationship with government.

3 Corporate ownership has more influence on performance than corporate size. With reference to ownership and size, we classified the companies into four categories: private big companies, private small companies, state-owned big companies and state-owned small companies. We used ordering test to identify the performance order of the four types of companies. Among them, private large companies show the best performance. From the results of the ordering test, this study confirmed that the role of ownership in China's TCM industry is greater than size. To understand this result it might be argued that private enterprises, thanks to their better governance and management mechanisms, are able to better exploit economies of scale.

4 The policy implications of this empirical investigation can be explored and discussed. The final results of our analysis might suggest that from an industrial policy perspective private large enterprise should be encouraged. Large and private should be considered beautiful. This could be the case but it is better to add further specifications. Company behaviours, management and performance are strongly influenced by the level of competition characterising one specific market. Private companies working in a monopoly setting, if protected from (domestic and foreign) 
new entries, have normally low incentives to perform efficiently. Vice versa, on the other extreme, state-owned enterprises operating in competitive markets might be highly efficient and innovative. For this reason it is better to be prudent in elaborating too-basic policy implications. Large and private can be beautiful but competition clearly matters. The crucial issue is connected to the evolution of this fast-growing sector. How is the Chinese TCM domestic industry going to change in the future? How will strategic company conducts change the domestic TCM market structure? What about the potential entry of foreign competitors? Given the present market structure and in the current competitive setting, our enquiry on the Chinese TCM listed companies shows that large private enterprises perform better. However, the structure of this fast-growing industry can be destined to change. Company efficiency is not just a matter of size and ownership. It is also connected to the rate of competition associated to one specific market in one specific period. Mergers, acquisitions, trusts, entries and exits might rapidly change the Chinese TCM industry structure. This kind of events has an impact on companies' performance going definitively beyond the issues of ownership. In this sector characterised by a relative low number of companies, will China need antitrust policies in the future? Moreover, so far the Chinese TCM Industry has tended to remain rather immune from foreign competition both in the domestic and in the international markets. Chinese consumers (in mainland China and living abroad) have a clear preference for Made-in-China TCM goods and this allows Chinese companies implicit advantages and protection. Furthermore, Made-in-China TCM is legally protected by quite strict import regulations that make export to China (from countries such as Japan or Korea) particularly difficult. For how long is this scenario going to be confirmed? This protected position, in the medium and long run, might lead to problems for the Chinese TCM industry. An isolated and protected industry has scarce incentives toward innovation, technological upgrading and efficiency. And a weak, inefficient a scarcely innovative TCM national industry may rapidly loose domestic market shares in case of an aggressive entries in the Chinese market of TCM and Western medicine (WM) foreign competitors. Despite the lower performance at present, will China need to follow national-champion strategy investing again in the role of stateowned enterprises?

\section{References}

Anderson, S.P., De Palma, A. and Thisse, J.F. (1997) 'Privatization and efficiency in a differentiated industry', European Economic Review, Vol. 41, No. 9, pp.1635-1654.

Arboretti, G.R., Bolzan, M., Bonnini, S., Corain, L. and Solmi, F. (2012) 'Advantages of closed testing method for multiple comparison procedures', Communications in Statistics - Simulation and Computation, Vol. 41, No. 6, pp.746-763.

Arboretti, G.R. and Bonnini, S. (2009) 'Nonparametric directional tests in the presence of confounding factors and categorical data', Statistica and Applicazioni, Vol. 7, No. 1, pp.87-103.

Bain, J.S. (1956) 'Advantages of the large firm: production, distribution and sales promotion', Journal of Marketing, Vol. 20, No. 4, pp.336-346.

Boardman, A.E. and Vining, A.R. (1989) 'Ownership and performance in competitive environments: a comparison of the performance of private, mixed, and state-owned enterprises', Journal of Law and Economics, Vol. 32, No. 1, pp.1-33. 
Bogart, D. and Chaudhary, L. (2015) 'Off the rails: is state ownership bad for productivity?', Journal of Comparative Economics, Vol. 43, No. 4, pp.997-1013.

Bonnini, S., Corain, L., Marozzi, M. and Salmaso, L. (2014) Nonparametric Hypothesis Testing: Rank and Permutation Methods with Applications in R, Wiley, Chichester.

Cornett, M.M., Guo, L., Khaksari, S. and Tehranian, H. (2010) 'The impact of state ownership on performance differences in privately-owned versus state-owned banks: an international comparison', Journal of Financial Intermediation, Vol. 19, No. 1, pp.74-94.

Daemmrich, A. (2013) 'The political economy of healthcare reform in China: negotiating public and private', in SpringerPlus, Vol. 2, No. 1, pp.448.

Di Tommaso, M.R. and Schweitzer, S.O. (2005) Health Policy and High-Tech Industrial Development: Learning from Innovation in the Health Industry, Edward Elgar Publishers, Cheltenham England.

Di Tommaso, M.R. and Huang, M. (2010) 'Knowledge transfer between universities, hospitals and industry: a case study of the traditional Chinese medicine industry', in International Journal Healthcare Technology and Management, Vol. 11, No. 4, pp.283-295.

Di Tommaso, M.R., Rubini, L. and Barbieri, E. (2013) Southern China: Industry, Development and Industrial Policy, Routledge, Milton Park Abingdon United Kingdom.

Feng, Z. (2009) 'The development of the traditional Chinese medicine industry in China and management measure, based on the theory of industrial innovation', Science and Technology Management Research, Vol. 8, pp.6-9.

Feng, Z. and Chang, X. (2010) 'Analysis of Chinese herbal medicines influence the choice of industrial organization model of economic factors', Agricultural Technology Economics, Vol. 5, pp.55-63.

Hao, G. (2011) Research on the Development Strategy of the Chinese Traditional Medicine Industry: in SCP Perspective, Vol. 5, Huazhong University of Science and Technology.

Huang, Y. (2013) Governing Health in Contemporary China, Routledge, Milton Park Abingdon United Kingdom.

Hanoch, G. (1975) 'The elasticity of scale and the shape of average costs,' American Economic Review, Vol. 65, No. 3, pp.492-497.

Jing, J. (2011) 'The relationship between concentration ratio and corporate performance of state-owned and private equity listing corporation of China's pharmaceutical industry comparative study', Product and Quality, Vol. 8, pp.88-89.

Li, N. and Hazel, J. (2010) 'State owned enterprises restructuring the empirical analysis based on the double difference model estimation', Quantity Economy and Technology Economy Research, Vol. 2, pp.3-21 [in Chinese].

Liu, R. and Shi, L. (2010) 'Study on the double loss of efficiency and economic growth', Economy of State-owned Enterprises, Vol. 1, pp.127-137 [in Chinese].

Liu, X. (2004) 'Analysis of privatization on Chinese industry efficiency', Economic Research, Vol. 8, pp.16-25 [in Chinese].

Millward, R. (1982), 'The comparative performance of public and private ownership', in Roll E. (Ed.): The Mixed Economy, pp.58-93, Palgrave Mc Millan, Basingstoke.

NBS (National Bureau of Statistics) (2014), China Statistical Yearbook, National Bureau of Statistics.

Färe, R., Grosskopf, S. and Logan, J. (1985) 'The relative performance of publicly-owned and privately-owned electric utilities', Journal of Public Economics, Vol. 26, No. 1, pp.89-106.

Panzar, J.C. and Willig, R.D. (1977) 'Economies of scale in multi-output production', Quarterly Journal of Economics, Vol. 91, No. 3, pp.481-493.

Parker, D. and Kirkpatrick, C. (2005) 'Privatisation in developing countries: a review of the evidence and the policy lessons', Journal of Development Studies, Vol. 41, No. 4, pp.513-541.

Silvestre, J. (1987) 'Economies and diseconomies of scale', The New Palgrave: A Dictionary of Economics, pp.80-84, Macmillan, London. 
Roland, G. (2008) Privatization: Successes and Failures, Columbia University Press, New York.

Rubini, L. and Barbieri, E. (2013) 'Percorsi evolutivi nel sostegno alle imprese in Cina. Un'analisi delle imprese leader e riflessioni sulla politica industriale', L'Industria - Rivista di Economia e Politica Industriale, Vol. 34, No. 3, pp.397-416.

Song, L. and Chang, Y. (2009) 'State owned and private industrial enterprises in the relative efficiency', Industrial Engineering and Management, Vol. 4, pp.122-142 [in Chinese].

Stigler, G.J. (1946) The Theory of Price, Rev. ed., MacMillan, New York.

VanderWeele, T.J. and Shpitser, I. (2013) 'On the definition of a confounder', Annals of Statistics, Vol. 41, No. 1, pp.196-220.

Viner, J. (1932) 'Cost curves and supply curves', Zeitschrift für Nationalökonomie, Vol. 3, No. 1, pp.23-46.

Vining, A.R. and Boardman, A.E. (1992) 'Ownership versus competition: efficiency in public enterprise', Public Choice, Vol. 73, No. 2, pp.205-239.

Wang, L. and Chen, Y. (2013) 'The productivity effect of agglomeration: evidence from Chinese manufacturing enterprises', Journal of Finance and Economics, Vol. 1, pp.49-60.

Wolf, C. (2009) 'Does ownership matter? The performance and efficiency of state oil vs. private oil (1987-2006)', Energy Policy, Vol. 37, No. 7, pp.2642-2652.

World Bank (1990) Proceedings of the Annual Conference on Development Economics, Supplement to the World Bank Economic Review and The World Bank Research Observer, World Bank Publications, Washington D.C.

World Bank (1996) World Development Report 1996: From Plan to Market, World Bank Publications, Washington D.C.

World Bank (2016) Healthy China: Deepening Health Reform in China Building High-Quality and Value-Based Service Delivery, World Bank Group, Washington, D.C.

World Health Organization (2013) WHO Traditional Medicine Strategy: 2014-2023, WHO Press, Geneva.

Yao, Y. (1998) 'Non state-owned economy component impact on the technical efficiency of industrial enterprises in China', Economic Research, Vol. 12, pp.29-33 [in Chinese].

Zhang, L. and Sun, J. (2010) 'Exports is to promote the growth of productivity of heterogeneous firms: from an empirical analysis of China's manufacturing enterprises', The Nankai Economic Studies, Vol. 4, pp.110-122.

Zhao, Z. (2015) 'Current situation and future trend of Chinese traditional medicine industry in China’, Journal of Nanjing University of Chinese Medicine, Vol. 1, pp.53-59 [in Chinese].

\section{Notes}

1 The research leading to these results has received funding from the People Programme (Marie Curie Actions) of the European Union's Seventh Framework Programme fp7/2007-2013/ under reA grant agreement no 612589. The publication does not necessarily reflect the opinion of the EU.

2 People's Republic of China, Twelfth Five-Year Plan for Health Sector Development 2011-2015.

3 For a discussion on the meaning of health Industry (Di Tommaso and Schweitzer, 2005).

4 The WHO reports Chinese official sources: Government of China, National Bureau of Statistics of China. China Statistical Yearbook 2011: Chinese Medicine (1987-2010). The State Administration of Traditional Chinese Medicine, China. (http://www.satcm.gov.cn/1987-2010/start.htm).

51 dollar $=6.90678$ yuan $($ March 2017). 
6 WHO uses the following definition: "The terms "complementary medicine" or "alternative medicine" refer to a broad set of health care practices that are not part of that country's own tradition or conventional medicine and are not fully integrated into the dominant health-care system. They are used interchangeably with traditional medicine in some countries (WHO, 2013). (http://www.who.int/medicines/areas/traditional/definitions/en/).

7 Chinese Pharmaceutical Yearbook, 2013; National Science and technology department and the Ministry of health, the national science agency sent word [2007] No. 77 "Chinese medicine innovation development plan (2006-2020)", 2007.

\section{Appendix}

Table A1 The listed TCM companies in 2014 in China

\begin{tabular}{|c|c|c|c|}
\hline Name & Listed year & Region & Ownership \\
\hline 云南白药 & 1993 & Yunnan & State-owned \\
\hline 白云山 & 2001 & Guangdong & State-owned \\
\hline 康美药业 & 2001 & Guangdong & Private \\
\hline 天士力 & 2002 & Tianjin & Private \\
\hline 同仁堂 & 1997 & Beijing & State-owned \\
\hline 中新药业 & 2001 & Tianjin & State-owned \\
\hline 太极集团 & 1997 & Chongqing & State-owned \\
\hline 昆药集团 & 2000 & Yunnan & Private \\
\hline 东阿阿胶 & 1996 & Shandong & State-owned \\
\hline 康恩贝 & 2004 & Zhejiang & Private \\
\hline 中恒集团 & 2000 & Guangxi & Private \\
\hline 益佰制药 & 2004 & Guizhou & Private \\
\hline 济川药业 & 2001 & Hubei & Private \\
\hline 以岭药业 & 2011 & Hebei & Private \\
\hline 红日药业 & 2009 & Tianjin & Private \\
\hline 江中药业 & 1996 & Jiangxi & State-owned \\
\hline 葵花药业 & 2014 & Heilongjiang & Private \\
\hline 康缘药业 & 2002 & Jiangsu & Private \\
\hline 信邦制药 & 2010 & Guizhou & Private \\
\hline 仁和药业 & 1996 & Jiangxi & Private \\
\hline 吉林敖东 & 1996 & Jilin & Private \\
\hline 千金药业 & 2004 & Hunan & State-owned \\
\hline 健民集团 & 2004 & Hubei & Private \\
\hline 贵州百灵 & 2010 & Guizhou & Private \\
\hline 香雪制药 & 2010 & Guangdong & Private \\
\hline
\end{tabular}


Table A1 The listed TCM companies in 2014 in China (continued)

\begin{tabular}{|c|c|c|c|}
\hline Name & Listed year & Region & Ownership \\
\hline 上海凯宝 & 2010 & Shanghai & Private \\
\hline 桂林三金 & 2009 & Guangxi & Private \\
\hline 片仔癀 & 2003 & Fujian & State-owned \\
\hline 九芝堂 & 2000 & Hunan & Private \\
\hline 众生药业 & 2009 & Guangdong & Private \\
\hline 太龙药业 & 1999 & Henan & State-owned \\
\hline 太安堂 & 2010 & Guangdong & Private \\
\hline 奇正藏药 & 2009 & Xizang & Private \\
\hline 羚锐制药 & 2000 & Henan & Private \\
\hline 益盛药业 & 2011 & Jilin & Private \\
\hline 紫金䔙业 & 2007 & Jilin & Private \\
\hline 汉森制药 & 2010 & Hunan & Private \\
\hline 恒康医疗 & 2008 & Gansu & Private \\
\hline 福瑞股份 & 2010 & Neimenggu & Private \\
\hline 精华制药 & 2010 & Jiangsu & State-owned \\
\hline 嘉应制药 & 2007 & Guangdong & Private \\
\hline 佐力药业 & 2011 & Zhejiang & Private \\
\hline 辅仁药业 & 1996 & Shanghai & Private \\
\hline 佛慈制药 & 2011 & Gansu & State-owned \\
\hline 台城制药 & 2014 & Guangdong & Private \\
\hline 沃华医药 & 2007 & Shandong & Private \\
\hline 紫光古汉 & 1996 & Hunan & State-owned \\
\hline 龙津药业 & 2015 & Yunnan & Private \\
\hline
\end{tabular}

